\title{
Unveiling the contribution of bee pollinators to Brazilian crops with implications for bee management
}

\author{
Tereza Cristina Giannini ${ }^{1,2}$, Denise Araujo Alves ${ }^{3}$, Ronnie Alves ${ }^{1,4}$, \\ Guaraci Duran CordeIro ${ }^{5}$, Alistair John CAMPBell ${ }^{6}$, Marcelo Awade ${ }^{1}$, \\ José Maurício Simões Bento ${ }^{3}$, Antonio Mauro SARAIVA ${ }^{2}$, \\ Vera Lucia IMPERATRIZ-FONSECA ${ }^{1,7}$ \\ ${ }^{1}$ Instituto Tecnológico Vale, Belém, Pará, Brazil \\ ${ }^{2}$ Departamento de Engenharia de Computação e Sistemas Digitais, Escola Politécnica, Universidade de São Paulo, Sao \\ Paulo, Sao Paulo, Brazil \\ ${ }^{3}$ Departamento de Entomologia e Acarologia, Escola Superior de Agricultura Luiz de Queiroz, Universidade de São \\ Paulo, Piracicaba, Sao Paulo, Brazil \\ ${ }^{4}$ Programa de Pós- Graduação em Ciência da Computação, Universidade Federal do Pará, Belém, Pará, Brazil \\ ${ }^{5}$ Department of Biosciences, University of Salzburg, Salzburg, Austria \\ ${ }^{6}$ Embrapa Amazônia Oriental, Belém, Pará, Brazil \\ ${ }^{7}$ Departamento de Ecologia, Instituto de Biociências, Universidade de São Paulo, Sao Paulo, Sao Paulo, Brazil
}

Received 19 February 2019 - Revised 23 September 2019 - Accepted 11 December 2019

\begin{abstract}
The need for basic information on tropical crop pollinators remains a key priority. Here, we used a dataset on Brazilian bee-crop interactions to determine important bee species for crop pollination and discuss their management in Brazilian croplands. We developed an analytical approach to select key bee species and genera from datasets based on different criteria, selecting only interactions reported as effective pollination events. Data on pollination included 261 records of unique crop-pollinator interaction, 144 bee species, and 23 crops. Despite the importance of social species, solitary bees accounted for $56 \%$ of the observed interactions. Of the 14 most important species, eight are solitary and six are social. A few of the selected species are already reared in Brazil, e.g., honeybees and some stingless bees, but practical knowledge on their management for crop pollination is poorly disseminated among farmers, hindering such an application.
\end{abstract}

\section{Agricultural production / Biodiversity / Ecosystem services / Tropical crop pollinators}

\section{INTRODUCTION}

Pollinators are under threat from factors associated with human activities, including habitat loss and degradation, pesticides, parasites, patho-

Electronic supplementary material The online version of this article (https://doi.org/10.1007/s13592-019-00727-3) contains supplementary material, which is available to authorized users.

Corresponding author: T. Giannini, tereza.giannini@itv.org

Manuscript Editor: David Tarpy gens, invasive species, and climate change, as demonstrated by the International Platform on Biodiversity and Ecosystem Services (IPBES 2016; Potts et al. 2016). To safeguard pollinators, the conservation of natural landscapes and the use of bee-friendly practices in agriculture should be promoted and implemented (Carvalheiro et al. 2011; Garibaldi et al. 2014; Dicks et al. 2016), which is considered a global priority (Brown et al. 2016). In the face of rising demand for pollinatordependent crops (Aizen et al. 2009), it is fundamental to identify key pollinator species with the dual goals of improving the effectiveness of 
pollinator management, i.e., beekeeping practices aiming to increase pollination of agricultural crops, and to encourage farmers to incorporate such practices into agricultural systems.

The functional role of animal pollinators is of paramount importance, since almost $90 \%$ of flowering plant species rely on them for fruit and/or seed set (Ollerton et al. 2011). Although the vital role of animal pollinators in maintaining wild plant communities that sustain biodiversity in terrestrial ecosystems is well established, a growing international focus on such pollinators has been directed toward food security (Potts et al. 2016). The role of pollinators as ecosystem service providers is well known since they improve the seed and/or fruit yield and quality of approximately $75 \%$ of global crop species that are important for the human diet (Klein et al. 2007). Animal pollination is an essential natural process that has a significant social and economic impact on agricultural outcomes, and its global economic value is estimated to be US\$235-577 billion annually (Potts et al. 2016).

Bees are considered as the most important crop pollinators worldwide (Klein et al. 2007). While Apis mellifera is the main managed pollinator species in many global crops (Potts et al. 2016), fruit set is more often dependent on the activities of diverse assemblages of wild pollinators (Garibaldi et al. 2013). Behavioral and morphological differences among flower-visitor species are predictors of pollination (Woodcock et al. 2013), and functional divergence of species traits was demonstrated as being important to crop yields (Woodcock et al. 2019). Therefore, crop yield and profits are likely to be increased by both management of specific pollinator species, and the promotion of wild pollinator richness, resulting in benefits to both farmers and society (Garibaldi et al. 2014).

Management of bee species is key to crop production, especially on places where wild bees present low abundance, such as intensive crop production fields with proportionally low natural lands on surroundings (Isaacs and Kirk 2010). Positive examples can be found throughout the world. Social bumblebee colonies have been reared and used in greenhouses to improve yield and quality of tomato crops (Velthuis and van
Doorn 2006). In the tropics, several stingless bee species can be reared in hives and used in the pollination of crops in both greenhouses and open fields (Heard 1999; Slaa et al. 2006). In other global regions, solitary bee species have been reared in artificial nests to improve pollination of nearby crops (e.g., Osmia, Megachile, Nomia species) (Cane 2008; Pitts-Singer and Cane 2011; Sedivy and Dorn 2014; MacIvor 2017). Thus, agricultural practices that integrate diversified managed and wild bee populations should be adopted to improve crop yields and farmers' profits while conserving biodiversity and ecosystem services (Garibaldi et al. 2013).

Few common bee species were reported as the main providers of crop pollination in the USA and Europe (Kleijn et al. 2015), but little is known about the main species for tropical regions (Archer et al. 2014), with many studies on pollination reporting only coarse levels of taxonomic resolution (Allen-Wardell et al. 1998; Giannini et al. 2015a; Eisenhauer et al. 2019). Brazil is an example of a megadiverse tropical country where greater focus on crop pollinators is required. Brazil produces more than $7 \%$ of global agricultural exports, making it the world's third-largest exporter of agricultural products (FAO 2014). Of all crop species cultivated in Brazil, more than $60 \%$ depend on, or benefit from, pollination provided mainly by 250 bee species (Giannini et al. $2015 \mathrm{a}, \mathrm{b}$ ), and approximately $30 \%$ of the annual agricultural value of these crops is directly derived from the activity of these pollinators (Giannini et al. 2015b). Moreover, Brazil has the second highest number of bee species of any country globally, with more than 1860 described species (Ascher and Pickering, 2018). However, given current predictions on population growth $(15 \%$ increase by 2030 (IBGE 2017)), demands on food production are expected to increase considerably, imposing environmental challenges due to the conversion of natural habitats into croplands and pastures (Gibbs et al. 2010). Knowing that the conversion of natural habitats has negative impacts on pollinators and pollination services, there is urgent need to identify key pollinator species and develop more pollinator-friendly approaches to enhance agricultural production (Garibaldi et al. 2017; Isaacs et al. 2017). 
In the present study, we aimed to determine the most important bee species for Brazilian crop pollination and discuss their management using a large dataset on bee-crop flower visitation that included only interactions considered as legitimate pollination events. Due to the high diversity of bees found in tropical regions, and existing knowledge gaps on tropical crop pollination, defining a list of important crop pollinator species and providing suggestions for their management can be extremely useful for both public policyand decision-making processes.

\section{MATERIAL AND METHODS}

The data used here is an update of two previous publications performed in Brazil. One of them is related to a bibliographical survey that was carried out on reported pollinators of agricultural crops (Giannini et al. 2015a). This first assessment analyzed 249 references and found 2545 interactions between pollinator and/or visitor species (totaling 321 animal species) with crops (85 crops). The other study determined the degree of dependence of Brazilian crops on animal pollination (Giannini et al. 2015b), using the original data on Klein et al. (2007) and 57 other articles specifically related to Brazilian crops. In total, 141 crops and their dependence on pollinators were evaluated. Data published by Klein et al. (2007) were updated where necessary.

These two abovementioned datasets were updated by using new publications (Online Resource 1 for full list) on the subject. Data were compiled as a table of interactions in which each row represents a bee species reported to pollinate a particular crop plant species all around Brazil. Interactions are represented as binary data since we do not have the number of bee individuals collected per observation (see Online Resource 2). As our objective is to identify the most important pollinating bees for Brazil, data related to bees reported as visitors were excluded. We did not develop our approach based on regional information, firstly because such data are scarce on Brazil, and secondly, because our objective is to provide a species list of Brazilian bees that could help on decision-making and stimulate new studies specially related to bee management to enhance crop production. Bee species with incomplete taxonomic identification were also removed from analysis. The scientific names of crop species were included in the Online Resource 1.

To determine the most important bee species, we used the following criteria: (C1) Centrality of the bee species in the crop-pollinator interaction network: within the context of mutualistic interaction networks, centrality refers to the capability of a particular node to influence others based on its structural position (Estrada and Bodin 2008), acting as a hub (i.e. a species with a large number of interactions) and/or as a connector (i.e. a species that connects different network's module) (Mello et al. 2015). Bee species that dominated most of the interactions with the agricultural crops were considered the most important. To identify such species, we tested five measures of network centrality available in the igraph package (Csardi and Nepusz 2006) for R (R Core Team 2015): (a) degree, which is the number of species' adjacent edges; (b) "coreness," where the k-core of graph is a maximal subgraph in which each vertex has at least degree k; (c) hub score or Kleinberg's hub centrality scores, where the hub scores of the vertices are defined as the principal eigenvector of $A * t(A)$, where $A$ is the adjacency matrix of the graph; (d) eigen centrality, where the eigenvector centrality scores correspond to the values of the first eigenvector of the graph adjacency matrix; (e) page rank, which calculates the Google PageRank for the specified vertices. As previously emphasized, we considered only presence/absence data (binary network) since the number of individuals of each bee species collected on each crop plant (weighted network) was not available. Because the overall correlation among the available measures was high $(>0.70)$, we used only one, the hub score. (C2) Geographic distribution of each bee species: species with a widespread geographical occurrence would be potentially more important as they provide pollination services across multiple regions. The distribution area was estimated from the occurrence points reported in the biodiversity data provider speciesLink (a Brazilian repository of biodiversity data from entomological collections) using convex hull tool in the QGIS (Open Source Geospatial Foundation Project). This tool determines the area of the smallest 
convex polygon that encloses all occurrence points of each species. (C3) Number of crops with which each bee species interacts: the higher the number of crops with which a particular bee species interacts, the greater that species' importance. As stated above, these data were updated from Giannini et al. (2015a). (C4) Pollinator dependency of each crop: the greater the dependence of the pollinated crop(s), the greater the importance of this pollinator for yield. So, bees that interact with crops that have a high dependence will receive a high score. Data about pollinator dependency is based on the differences of crop production with and without pollinators (Klein et al. 2007) and was taken from the literature about pollination of individual crops. This data was also updated from Giannini et al. (2015b). We considered the four dependency classes (originally used by Gallai and Vaissière 2009), who estimated the dependence rate (DR) for each class as follows: essential ( $\mathrm{DR}=0.95$; the value of pollination-driven yield lies between 90 and $100 \%)$; great $(\mathrm{DR}=0.65 ; 40$ $90 \%$ of yield is dependent on animal pollination); modest (DR $=0.25 ; 10-40 \%$ of yield is dependent on animal pollination); and little $(\mathrm{DR}=0.05 ; 0$ $10 \%$ of yield is dependent on animal pollination). (C5) Economic value of crop production: the higher the economic value of the crop(s) pollinated by a particular bee species, the greater its importance in this criterion. So, bees that interact with high-valued crops will reach a high score. Data were obtained from national lists that provide the values of annual agricultural production, which are available on the website of the Brazilian Institute of Geography and Statistics (IBGE) for 2015. To check for correlations among the criteria, we performed Pearson's product moment correlation using "stats" package for R (The R Project for Statistical Computing) and excluded criteria (C1) (centrality of the bee species in the crop-pollinator interaction network; $r=0.88, p<0.001$ ) and (C2) (geographic distribution of each bee species; $r=$ $0.81, p<0.001)$, since both were correlated with (C3) (number of crops pollinated by each bee species). In order to facilitate the interpretation of results, crop value (C4) and crop dependence (C5) were multiplied, following previous suggestion (Gallai and Vaissière 2009), aiming to estimate the value of pollination service for the analyzed crops. However, we also provide a comparison of bee species selected by each criterion in the Online Resource 2.

As each bee interacts with different crops, we summed all values of pollination service for each bee in order to obtain a unique value per bee species that refers to the value of pollination service of all crops for which we have data. We plotted the total value against the total number of crops with which each bee species interacts (C3). This plot is a graphic representation with four quadrants, which were defined by the following threshold values: a total value of pollination service of at least US $\$ 1$ billion, and at least three interactions. Since there is no other similar study published, we choose these limits empirically, analyzing our own data to obtain a viable number of species to guide decision-making processes. This limit was also selected after comparing other different limits with the results obtained by the abovementioned criteria (Online Resource 2); it was the one that selected the most similar set of species when compared to the species selected by all the criteria used.

We presented the same data considering bee genera and solitary and social bees. Bumblebees, honeybee, and stingless bees were classified as "social," and the other species were classified as "solitary." This simple division was assumed because in Brazil, traditionally, there is a historical emphasis on using social bee species for management, especially native stingless bees (Slaa et al. 2006, Jaffé et al. 2015) and the exotic Apis mellifera. However, details of sociality were included in the Online Resource 1 and in the text whenever necessary.

\section{RESULTS}

\subsection{Brazilian bee-crop interactions}

Data on crop pollinators included 261 records of bee-crop interactions involving 144 species of bees and 23 agricultural crops reported on 131 references (Online Resource 2). The genera with the highest number of species quoted were Centris (26 species), Xylocopa (12), Trigona (11), Epicharis , and Melipona (10 species each). 
Social bees comprised 63 species (44\%), and solitary, 81 species $(56 \%)$.

\subsection{Selected bee species}

Fourteen bee species presented the value of ecosystem services of pollination above our threshold ( $\geq 1$ bn US\$) and interacted with three or more crop species (quadrant 1 of Figure 1) (Table I). Apis mellifera presented the highest values for both variables, largely because of its importance in soybean production, which accounted for $66 \%$ of its total value of pollination service. Trigona spinipes presented the second highest value for number of interactions but was ranked tenth considering the total value of pollination service. Three species quoted in this quadrant belong to Centris ( $C$. aenea, C. similis,
C. tarsata), three species are stingless bees (Melipona quadrifasciata, Tetragonisca angustula, Trigona spinipes ), and two are bumblebees (Bombus morio, B. pauloensis). Tetragonisca angustula was reported as interacting with eight different crops. Xylocopa frontalis, also included in this quadrant, stands out interacting with seven crops. Altogether, eight species are solitary $(60 \%)$ and six are social (40\%).

One solitary bee species (Centris varia) presented a high total value of pollination service due to interactions with crops with high production in Brazil ( $\geq 1$ bn US\$), but was reported to pollinate only two crops (quadrant 2 of Figure 1).

Bee species with smaller values of pollination service and 1-2 interactions with crops comprise most of the analyzed species (121 species)

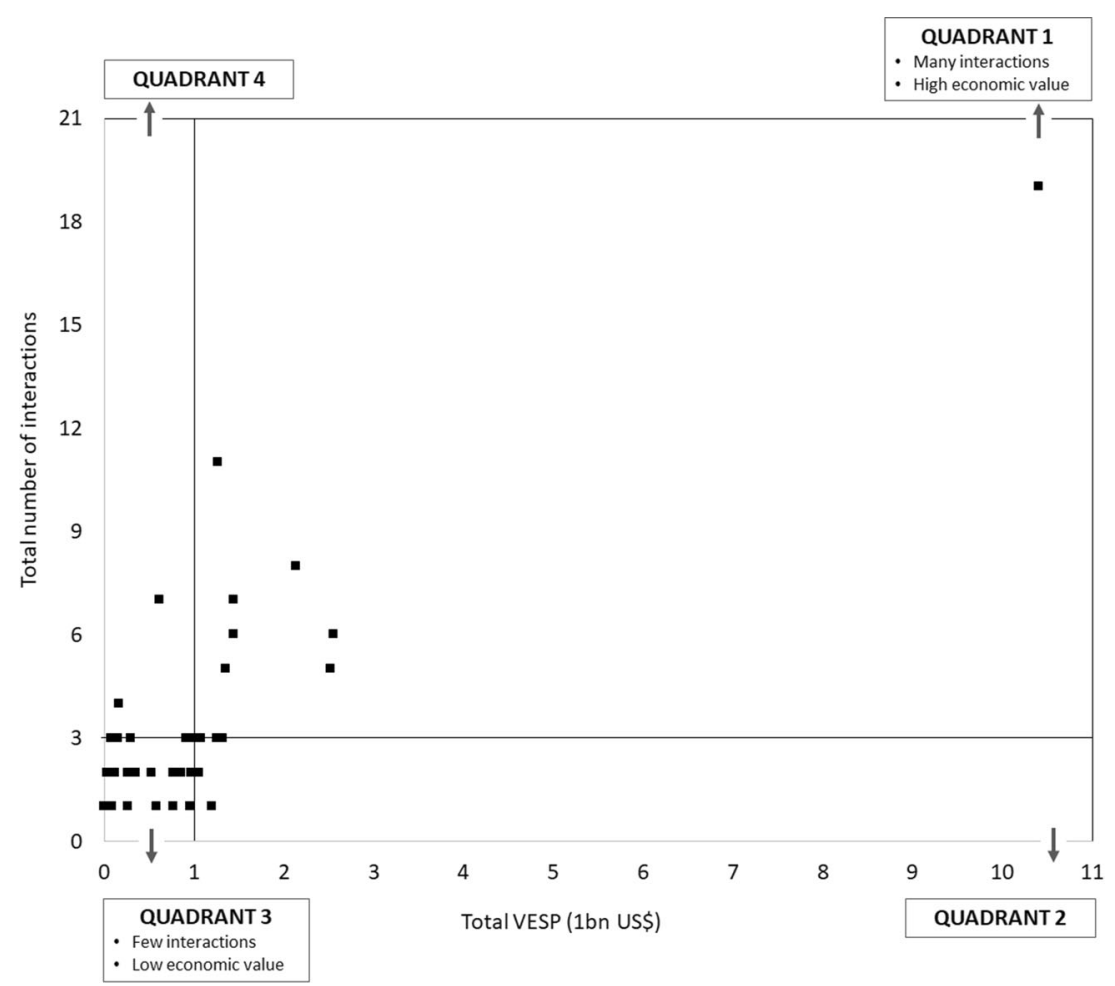

Figure 1 Representation of the criteria used for selecting the most important crop pollinators. Total value of ecosystem services of pollination (VESP) is the sum of all economic values of ecosystem services of pollination - calculated as the annual production of each crop (US\$, year 2015) multiplied by the crop dependence for animal pollination (see Material and Methods for details) — delivered by each bee in all crops (total number of interactions) pollinated by it. 
Unveiling the contribution of bee pollinators to Brazilian crops with implications for bee management 411

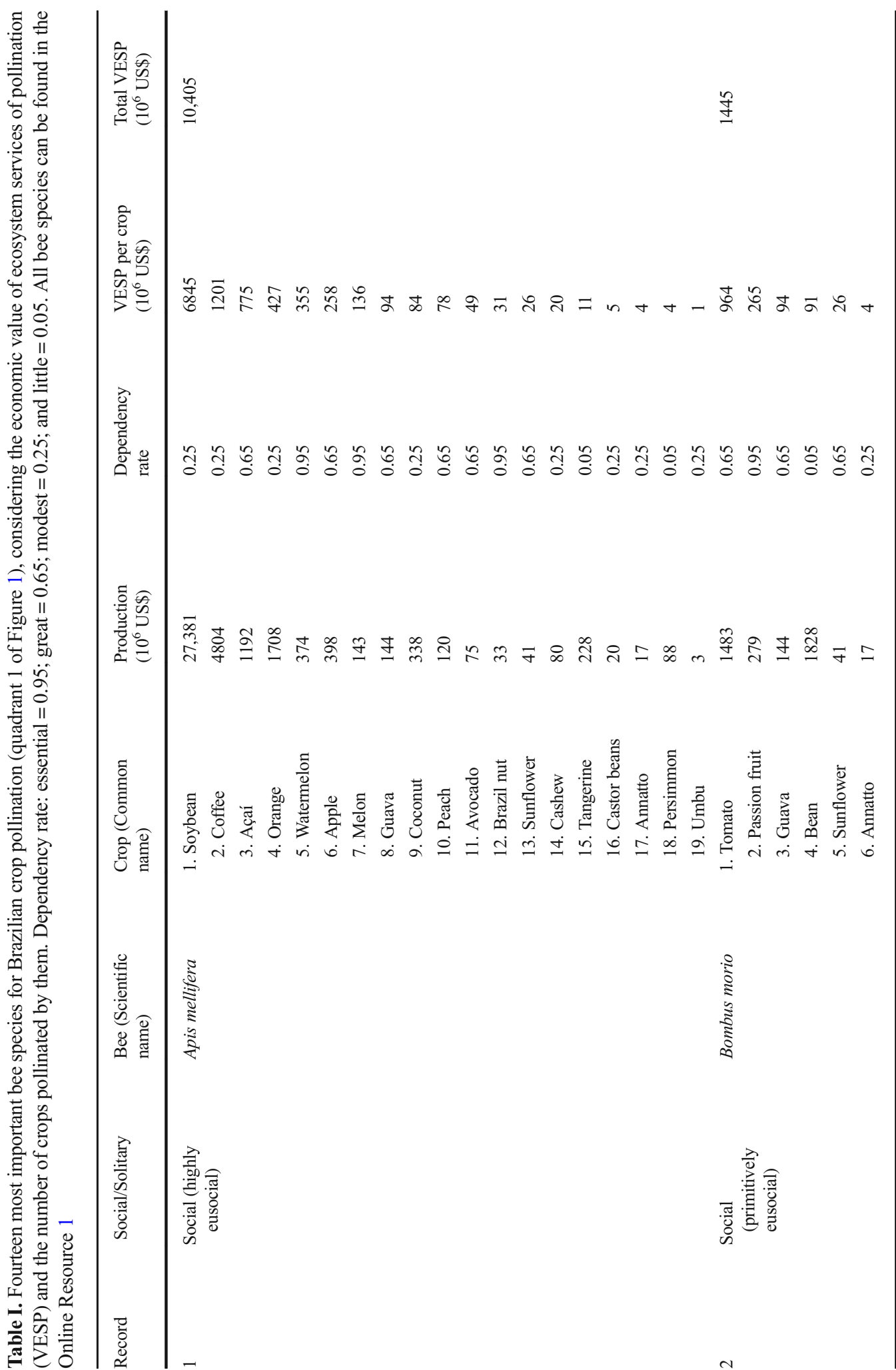




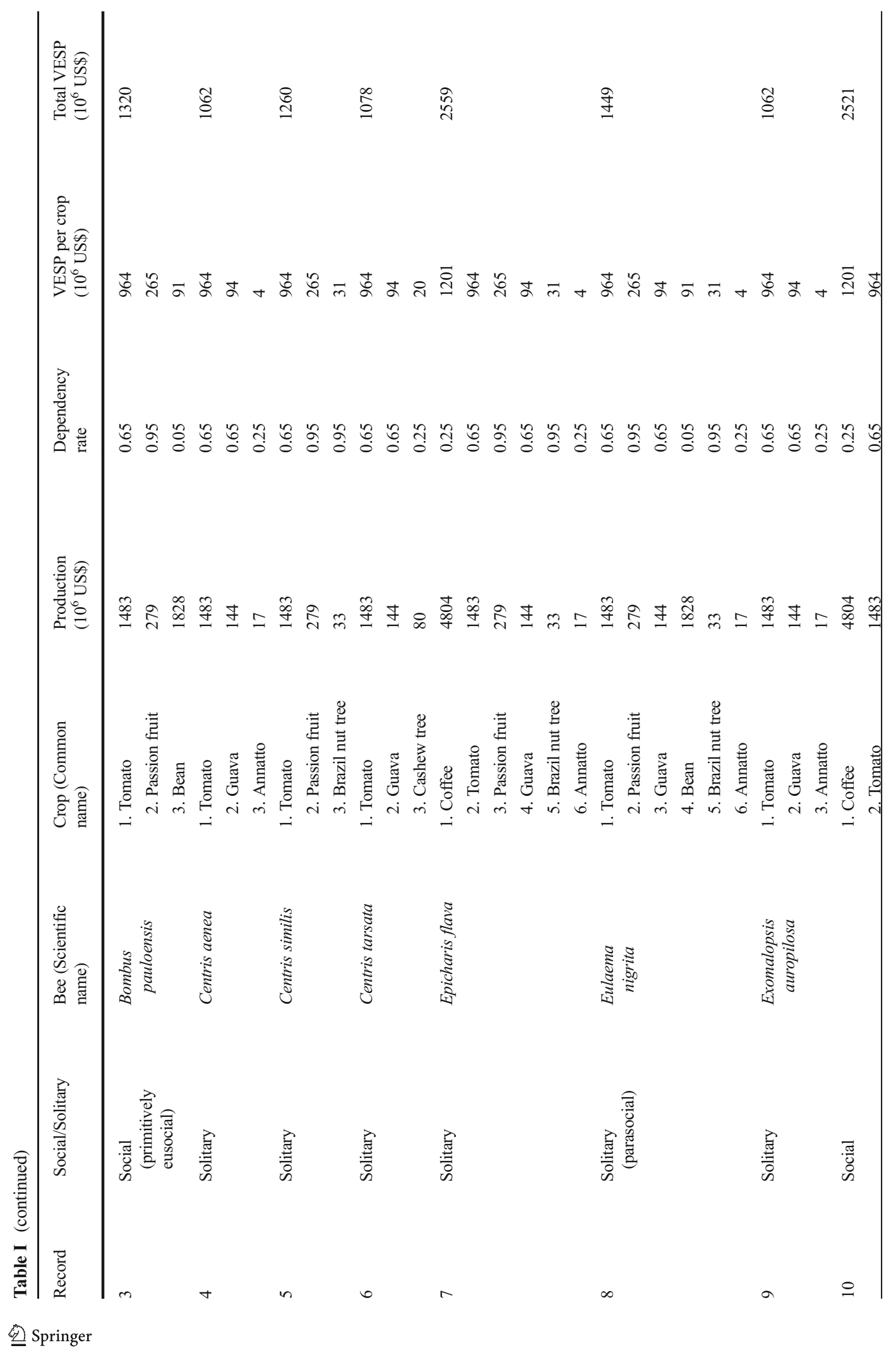




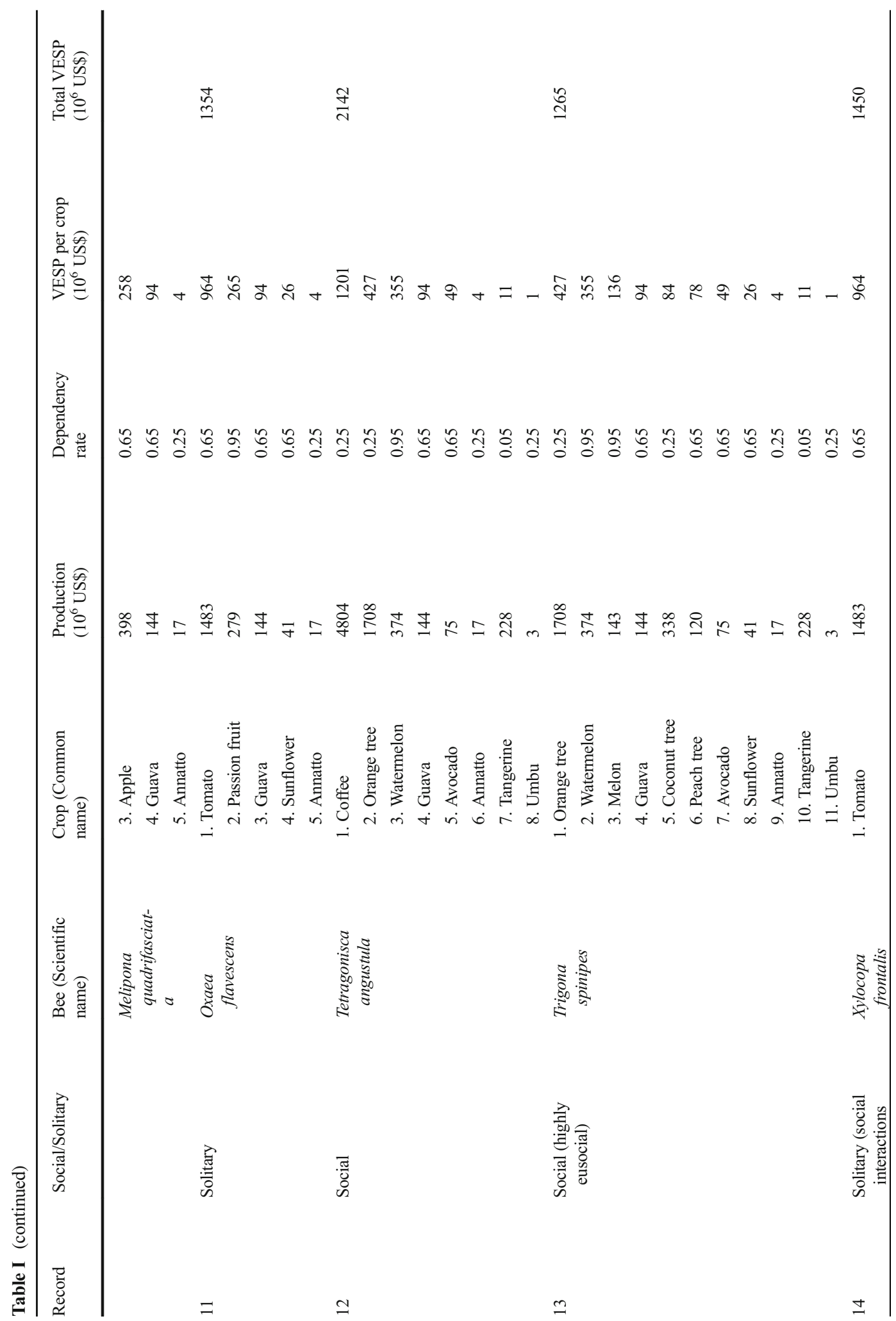


(quadrant 3 of Figure 1). Overall, 68 species are solitary $(56 \%)$ and 53 , social (44\%); and include 50 stingless bee species, 22 Centris, 9 Xylocopa, and 8 Epicharis .

Finally, bee species with high number of interactions but small total value of pollination service comprised eight species (quadrant 4 of Figure 1). Four species are stingless bees $(50 \%)$ and four species are solitary $(50 \%)$.

When comparing selected bee species using each of the used criteria and different thresholds, essentially, the same 14 species were selected (Online Resource 2). However, seven different species were selected using only geographic range (Centris rhodoprocta, Eulaema bombiformis, Eulaema cingulata, Eulaema meriana, Exaerete smaragdina, Trigona branneri, Trigona fulviventris) and two by centrality (Melipona fasciculata, Xylocopa grisescens). When using a smaller threshold for number of interaction $(\geq 2$ instead of $\geq 3$ ) and the same threshold for ecosystem services of pollination ( $\geq 1 \mathrm{bn}$ US\$), the list includes the 14 species previously quoted and also Centris varia. When using a higher threshold for ecosystem services of pollination ( $\geq 2 \mathrm{bn}$ US\$) and a smaller number of interaction $(\geq \overline{2})$, we obtained only four species, all of them included in the list of the 14 species (Apis mellifera, Epicharis flava, Melipona quadrifasciata, Tetragonisca angustula).

\subsection{Selected bee genera}

Considering bee genera, our results showed that 16 bee genera presented the value of pollination service higher than our threshold $(\geq$ US\$ 1 bn) (Table II; for complete list see Online Resource 1). Nine genera are social bees $(56 \%$ of total species), including a total of seven genera of stingless bees. The seven solitary bee genera quoted (44\%) were Augochloropsis, Centris, Epicharis, Eulaema, Exomalopsis, Oxaea, and Xylocopa .

\section{DISCUSSION}

Generalist bee species, mainly those interacting with crops presenting high monetary value (such as in decreasing order, soybean, coffee, tomato, 
Table II. Sixteen most important bee genera for Brazilian crop pollination, considering the economic value of ecosystem services of pollination (VESP) and the number of crops pollinated by them. All bee species and genera quoted can be found on Online Resource 1 and the number of species reported for each genus on Brazil can be found on Online Resource 3.

\begin{tabular}{llll}
\hline Genus & Total VESP $\left(10^{6}\right.$ US\$ $)$ & Nr. of bee species & Nr. of crops \\
\hline Apis & 10,405 & 1 & 19 \\
Melipona & 3413 & 10 & 10 \\
Trigona & 3241 & 11 & 13 \\
Bombus & 2677 & 5 & 8 \\
Eulaema & 2651 & 7 & 7 \\
Centris & 2584 & 26 & 8 \\
Epicharis & 2559 & 10 & 6 \\
Tetragonisca & 2142 & 2 & 8 \\
Partamona & 2118 & 6 & 4 \\
Scaptotrigona & 2003 & 4 & 4 \\
Paratrigona & 1976 & 2 & 2 \\
Xylocopa & 1617 & 12 & 5 \\
Oxaea & 1354 & 2 & 5 \\
Frieseomelitta & 1308 & 4 & 3 \\
Exomalopsis & 1062 & 4 & 2 \\
Augochloropsis & 1058 & 3 & \\
\hline
\end{tabular}

açaí, orange), were found to be the most important for crop pollination. Even for crops with modest dependence on pollinators, such as soybean, coffee, and orange, their high monetary value increased the scores of these bee species. Apis mellifera achieved a high score considering number of interactions and total pollination service value. Trigona spinipes also stood out with a high number of interactions but involving crops of comparatively low monetary value. From the 14 most important species highlighted here, eight are solitary. Solitary species were also involved in the highest number of the analyzed interactions.

\subsection{Social bee species and their management}

The importance of honeybee and stingless bees was expected, given their populous and perennial colonies require year-round nutritional supply to ensure their survival (Michener 1974; Maia-Silva et al. 2016). Additionally, as a group, stingless bees exploit a wide array of flowering crops through their diversity in body size and foraging strategies (reviewed in Jarau and Hrncir 2009). Apis mellifera is an exotic species in Brazil, and is the most important crop pollinator in the world (Potts et al. 2016). The high value of pollination service obtained here to A. mellifera is due mostly to the production of soybean that, in spite of being only modestly dependent on animal pollination, presents the highest value of production in Brazil (Giannini et al. 2015b). But this dependence requires further analysis since different varieties are cultivated, probably with different levels of pollination dependence. Additionally, the populous colonies of this exotic species (approximately 35,000 individuals; Eckert et al. 1994) might potentially affect the pollination performed by native pollinators through exploitative competition (Butz-Huryn 1997; Roubik and Villanueva-Gutierrez 2009; Lindström et al. 2016). A global study showed that native bees are more efficient than A. mellifera in crop pollination (Garibaldi et al. 2013), but the integration of 
wild bees and honeybees produces a greater proportion of fruit set than either species of bee alone (Greenleaf and Kremen 2006; Brittain et al. 2013).

Trigona spinipes is a widely distributed native stingless bee species. Their populous colonies (up to 180,000 individuals; Kerr 1951) are not dependent on specific habitats to build their nests, nor restricted to feeding on specific flowering plant species (considered "supergeneralist," Giannini et al. 2015c), allowing them to disperse easily through agricultural landscapes and provide pollination services in degraded habitats. In some cases, this species is unjustly considered as a pest by farmers (Renner 1983) as they aggressively defend their nests and have been shown to be nectar robbers in some crop species. But, as shown here, this species is also an important pollinator. However, the breeding of $T$. spinipes was tested without success (Shackleton et al. 2015).

Other social bees quoted here are being managed in artificial hives for greenhouse crop pollination in Brazil. Important examples are Tetragonisca angustula for strawberry (Fragaria ananassa, Malagodi-Braga and Kleinert 2004) and Melipona fasciculata for eggplant (Solanum melongena L., Nunes-Silva et al. 2013), with encouraging results in relation to pollination rate and fruit quality. Despite this, stingless bee management is still not used in Brazil at the scale needed for crop pollination. While the breeding of stingless bees is widely established in Brazil (Jaffé et al. 2015), there is a huge potential for commercial pollination (Cortopassi-Laurino et al. 2006).

Brazilian Bombus species, as the two selected species B. pauloensis and B. morio, are widespread and important to Brazilian crops (Giannini et al. 2015a). They are primitively eusocial with annual colonies. They differ from commonly managed European bumblebee species (e.g., Bombus terrestris) that have been commercialized by biofactories and delivered to many countries over the last decades to pollinate in greenhouses (Velthuis and van Doorn, 2006). Moreover, the number of Brazilian species is low when compared to the northern hemisphere (Ascher and Pickering, 2018) and studies toward their management are still incipient in Brazil.

\subsection{Solitary bee species and their management}

We showed that several solitary species are particularly important when considering crop pollination, especially Centris species. Centris is a genus with high number of identified species in Brazil (Online Resource 3), and further studies on their potential use in agricultural areas should be encouraged. Pioneering studies in Brazil have already shown the potential of trap nests to attract C. analis females in crops of acerola (Malpighia emarginata, (Magalhães and Freitas 2013; Oliveira and Schlindwein 2009).

Carpenter bees (Xylocopa), despite being considered here as a solitary species, exhibit different levels of sociality (Gerling et al. 2003). They efficiently pollinate Brazilian passion fruits (Passiflora spp.), and trap or artificial nests were successfully established in passion fruit orchards to enhance their populations and minimize pollination deficits (Freitas and Oliveira-Filho 2003; Junqueira and Augusto 2017). Carpenter bees have been also managed successfully in Israel (Sadeh et al. 2007) and Australia (Hogendoorn et al. 2006). For the other solitary species emphasized here (Epicharis flava, Eulaema nigrita, Exomalopsis auropilosa, and Oxaea flavescens), there is almost no information regarding management, except Eulaema nigrita, that was previously captured on nest traps (Garófalo et al. 2004).

Few other examples of managed solitary species are currently found globally for crop pollination. As already said, Osmia mason bees are used commercially in fruit orchards in Asia, Europe, and North America (Bosch and Kemp 2001; Sedivy and Dorn 2014; MacIvor 2017). Also, the leafcutter bee Megachile rotundata is used on alfalfa crops (Medicago sativa), being considered the most efficient pollinator of this crop in North America (PittsSinger and Cane 2011). Additionally, successful examples of artificial nesting sites indicate that they may be a good strategy to manage solitary bees to ensure pollination services for crops. However, the knowledge to manage these solitary bees still needs to be improved as regards nesting habitat, nest structure, building materials, resources provided to the larvae, period of nest occupancy, associated 
parasites, and mortality. Unfortunately, for most solitary bee species in Brazil, not even their nesting habits are known.

\subsection{Other selected species}

Our approach based on multiple criteria and thresholds captured similar species as the most important for crop pollination. Considering species with wide geographic ranges, the importance of Eulaema and Exaerete species, two genera of orchid bees, pollinators of passion fruit, brazil nut and annatto, is clear, alongside one species of Centris and two Trigona. The species Melipona fasciculata and Xylocopa grisescens were also selected based on their high centrality scores from the pooled bee-crop network. The latter species stands out, presenting interactions with seven crops. However, most of these crops present low economic values, which greatly diminished the importance of this species according to our criteria. The four species selected with the highest threshold of value of pollination service $(\geq 2 \mathrm{bn}$ US\$) were associated mainly to crops with the highest values on Brazil: soybean, coffee, açaí, and orange (Apis mellifera); coffee and tomato (Epicharis flava, Melipona quadrifasciata); and coffee and orange (Tetragonisca angustula). All of them are within the 14 bee species selected.

\subsection{Caveats and future steps}

Data on the geographic distribution of bees that occur in Brazil have been structured and made available mainly through the Moure's Bee Cata$\log$ (Moure et al. 2012) and the Brazilian biodiversity data provider, speciesLink (http://splink. cria.org.br/). However, data for the northern and central western regions of the country still need to be improved (Giannini et al. 2015a; but see Lima and Silvestre 2017), requiring additional field sampling effort.

Among all the crop-pollinator species mentioned here, information on nesting biology can be found for only 59 species (Online Resource 1), 37 being social, and 22 solitary species. Bee species that nest in aboveground cavities are much easier to manage (Michener 2007), and there are already several model systems for such species
(Mader et al. 2010). Studies on nesting biology are important to help on understanding species requirements and improve management techniques, and further studies should be encouraged.

The lack of data on bee species abundance in different regions and in crop lands also deserves attention, as more locally abundant pollinator species would be more important to crop yield. However, this data is still scarce and unreliable to be used in more general analytical approaches such as ours presented here. We also emphasize the need for more data on the production of agricultural crops, especially considering local crops. Brazil has a high diversity of regional crops, but little is known about their value of annual production, which hinders the type of analysis developed here. Moreover, little is known about the interactions of regional crops with pollinators. Regional crops could rely on more specialized pollinators, probably with more restricted distributions, but this needs further research. Thus, future studies should prioritize obtaining local data on regional crop production, understanding their dependence on pollinators, and which are the main pollinator species in the region, which would enable a more spatially refined perspective of pollination services. Given the importance of pollination for smallholder farming for local and regional economies (Garibaldi et al. 2016), this knowledge can be useful to guide local decision-making processes, which would be of great importance to farmers and local communities.

\section{CONCLUSIONS}

Current knowledge gaps on crop pollinator bees in tropical region must be addressed in order to help decision-making processes, particularly regarding solitary bees and bee management in general. We hope that the list provided here of the most important bee species for crop production can pave the road ahead of other studies and help develop new strategies for the sustainable management and conservation of crop pollinators. We emphasize that most Brazilian farmers are not aware of the benefits of pollination, so that many crops rely exclusively on wild pollinators. For this reason, bee management for crop pollination purposes still needs to be promoted and improved. Since the country has a high production of 
pollinator-dependent crops, bee management for commercial pollination is a great business opportunity.

\section{ACKNOWLEDGMENTS}

We thank Beatriz Woiski Teixeira Coelho, Rafael Cabral Borges and Rodolfo Jaffé for suggestions.

\section{AUTHORS' CONTRIBUTION}

TCG, DAA, GDC conceived this research; TCG and GDC provided the data; TCG, RA, MA, and AJC performed the analysis; TCG, DAA, and GDC wrote the paper. All the authors read, reviewed, and approved the final manuscript.

\section{FUNDING INFORMATION}

The Conselho Nacional de Desenvolvimento Científico e Tecnológico (CNPq, 472702/2013-0 to TGC and $149154 / 2018-6$ to DAA) and the Coordenação de Aperfeiçoamento de Pessoal de Nível Superior-Brasil (CAPES) - Finance Code 001 (to DAA) provided financial support.

Contribution des abeilles pollinisatrices aux cultures brésiliennes et les implications pour la gestion des abeilles.

production agricole / biodiversité / services écosystémiques / pollinisateurs des cultures tropicales / soja.

Der Beitrag von bestäubenden Bienen für brasilianische Kulturpflanzen und Implikationen für die Bienenhaltung.

landwirtschaftliche Produktion / Biodiversität / Ökosystembeitráge / Bestäuber tropischer Kulturpflanzen / Sojabohne.

\section{REFERENCES}

Aizen M., Garibaldi L., Cunningham S., Klein A. (2009) How much does agriculture depend on pollinators? Lessons from long-term trends in crop production. Ann Bot 103, 1579-1588. https://doi.org/10.1093 /aob/mcp076
Allen-Wardell G., Bernhardt P., Bitner R., Burquez A., Buchmann S., Cane J., Cox P.A., Dalton V., Feinsinger P., Ingram M. (1998) The potential consequences of pollinator declines on the conservation of biodiversity and stability of food crop yields. Conserv Biol 12, 817

Archer C.R., Pirk C.W.W., Carvalheiro L.G., Nicolson S.W. (2014) Economic and ecological implications of geographic bias in pollinator ecology in the light of pollinator declines. Oikos 123, 401-407. https://doi. org/10.1111/j.1600-0706.2013.00949.x

Ascher J.S., Pickering J. (2018) Discover life: bee species guide and world checklist (Hymenoptera: Apoidea: Anthophila). http://www.discoverlife.org/mp/20 q?guide $=$ Apoidea species \&flags $=$ HAS. Accessed 31 January 2019

Bosch J., Kemp W.P. (2001) How do manage the bleu orchard bee as on orchard pollinator. Sustainable Agriculture Network, Beltsville

Brittain C., Williams N., Kremen C., Klein A.M. (2013) Synergistic effects of non-Apis bees and honey bees for pollination services. Proc R Soc B 280, 20122767. https://doi.org/10.1098/rspb.2012.2767

Brown M.J.F., Dicks L.V., Paxton R.J., Baldock K.C.R., Barron A.B., Chauzat M.P., Freitas B.M., Goulson D., Jepsen S., Kremen C., Li J., Neumann P., Pattemore D.E., Potts S.G., Schweiger O., Seymour C.L., Stout J.C. (2016) A horizon scan of future threats and opportunities for pollinators and pollination. PeerJ 4, e2249. https://doi.org/10.7717/peerj.2249

Butz-Huryn V.M. (1997) Ecological impacts of introduced honey bees. Q Rev Biol 72, 275-297. https://doi. org/10.1086/419860

Cane J.H. (2008) A native ground-nesting bee (Nomia melanderi) sustainably managed to pollinate alfalfa across an intensively agricultural landscape. Apidologie 39, 315-323. https://doi.org/10.1051 /apido:2008013

Carvalheiro L.G., Veldtman R., Shenkute A.G., Tesfay G.B., Pirk C.W.W., Donaldson J.S., Nicolson S.W. (2011) Natural and within-farmland biodiversity enhances crop productivity. Ecol Lett 14, 251-259. https://doi.org/10.1111/j.1461-0248.2010.01579.x

Cortopassi-Laurino M., Imperatriz-Fonseca V.L., Roubik D.W., Dollin A., Heard T., Aguilar I., Venturieri G., Eardley C., Nogueira-Neto, P. (2006) Global meliponiculture: challenges and opportunities. Apidologie 37, 275-292. https://doi.org/10.1051 /apido:2006027

Csardi G., Nepusz T. (2006) The igraph software package for complex network research. Inter J Complex Syst $1695,1-9$

Dicks L.V., Viana B., Bommarco R., Brosi B., Arizmendi M.C., Cunningham S.A., Galetto L., Hill R., Lopes A.V., Pires C., Taki H., Potts S.G. (2016) Ten policies for pollinators. Science 354, 975-976. https://doi. org/10.1126/science.aai9226

Eckert C.D., Winston M.L., Ydenberg R.C. (1994) The relationship between population size, amount of brood, and individual foraging behaviour in the honey bee, 
Apis mellifera L. Oecologia 97, 248-255. https://doi. org/10.1007/BF00323157

Eisenhauer N., Bonn A., Guerra C.A. (2019) Recognizing the quiet extinction of invertebrates. Nat Commun 10, 50. https://doi.org/10.1038/s41467-018-07916-1

Estrada E., Bodin O. (2008) Using network centrality measures to manage landscape connectivity. Ecol Appl 18, 1810-1825. https://doi.org/10.1890/07-1419.1

FAO (2014) Country fact sheet on food and agriculture policy trends: Brazil. Food and Agriculture Policy Decision Analysis (FAPDA) team at FAO with the contribution of the FAO Regional Office for Latin America and the Caribbean. http://www.fao. org/docrep/field/009/i3759e/i3759e.pdf. Accessed 08 April 2018

Freitas B.M., Oliveira-Filho J.H. (2003) Rational nesting box to carpenter bees (Xylocopa frontalis) in the pollination of passion fruit (Passiflora edulis). Ciênc Rural 33, 1135-1139

Gallai N., Vaissière B. (eds) (2009) Guidelines for the economic valuation of pollination services at a national scale. Food and Agriculture Organization, Rome

Garibaldi L.A., Steffan-Dewenter I., Winfree R., Aizen M.A., Bommarco R., Cunningham S.A., Kremen C., Carvalheiro L.G., Harder L.D., Afik O., Bartomeus I., Benjamin F., Boreux V., Cariveau D., Chacoff N.P., Dudenhöffer J.H., Freitas B.M., Ghazoul J., Greenleaf S., Hipólito J., Holzschuh A., Howlett B., Isaacs R., Javorek S.K., Kennedy C.M., Krewenka K., Krishnan S., Mandelik Y., Mayfield M.M., Motzke I., Munyuli T., Nault B.A., Otieno M., Petersen J., Pisanty G., Potts S.G., Rader R., Ricketts T.H., Rundlöf M., Seymour C.L., Schüepp C., Szentgyörgyi H., Taki H., Tscharntke T., Vergara C.H., Viana B.F., Wanger T.C., Westphal C., Williams N., Klein A.M. (2013) Wild pollinators enhance fruit set of crops regardless of honey bee abundance. Science 339, 1608-1611. https://doi.org/10.1126/science. 1230200

Garibaldi L.A., Carvalheiro L.G., Leonhardt S.D., Aizen M.A., Blaauw B.R., Isaacs R., Kuhlmann M., Kleijn D., Klein A.M., Kremen C. (2014) From research to action: enhancing crop yield through wild pollinators. Front Ecol Environ 12, 439-447. https://doi. org/10.1890/130330

Garibaldi L.A., Carvalheiro, L.G., Vaissière, B.E., Gemmill-Herren, B., Hipólito, J., Freitas, B.M., Ngo, H.T., Azzu, N., Sáez, A., Åström, J., An, J., Blochtein, B., Buchori, D., García, F.J.C., Silva, F.O., Devkota, K., Ribeiro, M.F., Freitas, L., Gaglianone, M.C., Goss, M., Irshad, M., Kasina, M., Pacheco Filho, A.J.S., Kiill, L.H.P., Kwapong, P., Parra, G.N., Pires, C., Pires, V., Rawal, R.S., Rizali, A., Saraiva, A.M., Veldtman, R., Viana, B.F., Witter, S., Zhang, H. (2016) Mutually beneficial pollinator diversity and crop yield outcomes in small and large farms. Science 351, 338-391. DOI: https://doi.org/10.1126/science.aac7287

Garibaldi L.A., Gemmill-Herren B., D’Annolfo R., Graeub B.E., Cunningham S.A., Breeze T.D. (2017) Farming approaches for greater biodiversity, livelihoods, and food security. Trends Ecol Evol 32, 68-80. https://doi.org/10.1016/j.tree.2016.10.001
Garófalo C.A., Martins C.F., Alves-dos-Santos I. (2004) The Brazilian solitary bee species caught in trap nests, in: Freitas B.M. and Pereira J.O.P. (Eds.) Solitary Bees: conservation, rearing and management for pollination. Imprensa Universitária, Fortaleza, pp 77-84

Gerling D., Velthuis H.H.W., Hefetz A. (2003) Bionomics of the large carpenter bees of the genus Xylocopa. Annu Rev Entomol 34, 163-190. https://doi. org/10.1146/annurev.en.34.010189.001115

Giannini T.C., Boff S., Cordeiro G.D., Cartolano Jr E.A., Veiga A.K., Imperatriz-Fonseca V.L., Saraiva A.M. (2015a) Crop pollinators in Brazil: a review of reported interactions. Apidologie 46, 209-223. https://doi. org/10.1007/s13592-014-0316-Z

Giannini T.C., Cordeiro G.D., Freitas B.M., Saraiva A.M., Imperatriz-Fonseca V.L. (2015b) The dependence of crops for pollinators and the economic value of pollination in Brazil. J Econ Entomol 108, 849-857. https://doi.org/10.1093/jee/tov093

Giannini T.C., Garibaldi L.A., Acosta A.L., Silva J.S., Maia K.P., Saraiva A.M., Guimarães Jr P.R., Kleinert A.M.P. (2015c) Native and non-native supergeneralist bee species have different effects on plant-bee networks. PLoS One 10, e0137198. https://doi.org/10.1371/journal.pone. 0137198

Gibbs H.K., Ruesch A.S., Achard F., Clayton M.K., Holmgren P., Ramankutty N., Foley J.A. (2010) Tropical forests were the primary sources of new agricultural land in the 1980s and 1990s. Proc Natl Acad Sci U S A 107, 16732-16737. https://doi.org/10.1073 /pnas.0910275107

Greenleaf S.S., Kremen C. (2006) Wild bees enhance honey bees' pollination of hybrid sunflower. Proc Natl Acad Sci U S A 103, 13890-13895. https://doi. org/10.1073/pnas.0600929103

Heard T.A. (1999) The role of stingless bees in crop pollination. Annu Rev Entomol 44, 183-206. https://doi. org/10.1146/annurev.ento.44.1.183

Hogendoorn K., Gross C.L., Sedgley M., Keller M.A. (2006) Increased tomato yield through pollination by native Australian Amegilla chlorocyanea (Hymenoptera: Anthophoridae). J Econ Entomol 99, 828-833. https://doi.org/10.1093/jee/99.3.828

IBGE (2017) Sistema IBGE de Recuperação Automática SIDRA. https://sidra.ibge.gov.br/home/pimpfbr/brasil. Accessed 11 December 2017

IPBES (2016) Summary for policymakers of the assessment report of the Intergovernmental Science-Policy Platform on Biodiversity and Ecosystem Services on pollinators, pollination and food production. Secretariat of the Intergovernmental Science-Policy Platform on Biodiversity and Ecosystem Services, Bonn, Germany. 36 pages. http://www.ipbes.net/. Accessed 26 April 2018

Isaacs R., Kirk AK. (2010) Pollination services provided to small and large highbush blueberry fields by wild and managed bees. J Appl Ecol 47, 841-849. https://doi. org/10.1111/j.1365-2664.2010.01823.x

Isaacs R., Williams N., Ellis J., Pitts-Singerd T.L., Bommarco R., Vaughan M. (2017) Integrated Crop 
Pollination: Combining strategies to ensure stable and sustainable yields of pollination-dependent crops. Basic Appl Ecol 22, 44-60. https://doi.org/10.1016/j. baae.2017.07.003

Jaffé R., Pope N., Carvalho A.T., Maia U.M., Blochtein B., Carvalho C.A.L., Carvalho-Zilse G.A., Freitas B.M., Menezes C., Ribeiro M.F., Venturieri G.C., ImperatrizFonseca V.L. (2015) Bees for development: Brazilian survey reveals how to optimize stingless beekeeping. PLoS One 10, 1-21. https://doi.org/10.1371/journal. pone. 0121157

Jarau S., Hrncir M. (eds) (2009) Food exploitation by social insects: ecological, behavioral, and theoretical approaches. CRC Press, Taylor \& Francis Group, Boca Raton

Junqueira C.N., Augusto S.C. (2017) Bigger and sweeter passion fruits: effect of pollinator enhancement on fruit production and quality. Apidologie 48, 131-140. https://doi.org/10.1007/s13592-016-0458-2

Kerr W.E. (1951) Bases para o estudo da genética de populações de Hymenoptera em geral e dos Apinae sociais em geral. An Esc Sup Agric "Luiz de Queiroz" $8,219-354$.

Klein A.M., Vaissière B.E., Cane J.H., Steffan-Dewenter I., Cunningham S.A., Kremen C., Tscharntke T. (2007) Importance of pollinators in changing landscapes for world crops. Proc R Soc B 274, 303-313. https://doi. org/10.1098/rspb.2006.3721

Kleijn D., Winfree R., Bartomeus I., Carvalheiro L.G., Henry M., Isaacs R., Klein A.M., Kremen C., M'Gonigle L., Rader R., Ricketts T.H., Williams N.M., Adamson N.L., Ascher J.S., Báldi A., Batáry P., Benjamin F., Biesmeijer J.C., Blitzer E.J., Bommarco R., Brand M.R., Bretagnolle V., Button L., Cariveau D.P., Chifflet R., Colville J.F., Danforth B.N., Elle E., Garratt M.P.D., Herzog F., Holzschuh A., Howlett B.G., Jauker F., Jha S., Knop E., Krewenka K.M., Féon V., Mandelik Y., May E.A., Park M.G., Pisanty G., Reemer M., Riedinger V., Rollin O., Rundlöf M., Sardiñas H.S., Scheper J., Sciligo A.R., Smith H.G., Steffan-Dewenter I., Thorp R., Tscharntke T., Verhulst J., Viana B.F., Vaissière B.E., Veldtman R., Ward K.L., Westphal C., Potts S.G. (2015) Delivery of crop pollination services is an insufficient argument for wild pollinator conservation. Nat Commun 6, 7414 . DOI: https://doi.org/10.1038/ncomms8414.

Lima F.V.O., Silvestre R. (2017) Checklist of bees (Hymenoptera, Apidae sensu lato ) from Mato Grosso do Sul state, Brazil. Iheringia 107, e2017123. https://doi. org/10.1590/1678-4766e2017123

Lindström S.A., Herbertsson L., Rundlöf M., Bommarco R., Smith H.G. (2016) Experimental evidence that honeybees depress wild insect densities in a flowering crop. Proc R Soc B 283, 20161641. https://doi. org/10.1098/rspb.2016.1641

MacIvor J.S. (2017) Cavity-nest boxes for solitary bees: a century of design and research. Apidologie 48, 311327. https://doi.org/10.1007/s13592-016-0477-z

Mader E., Spivak M., Evans E. (2010) Managing alternative pollinators: a handbook for beekeepers, growers and conservationists. SARE Handbook 11, NRAES186, Maryland

Magalhães C.B., Freitas B.M. (2013) Introducing nests of the oil-collecting bee Centris analis (Hymenoptera: Apidae: Centridini) for pollination of acerola (Malpighia emarginata) increases yield. Apidologie 44, 234-239. https://doi.org/10.1007/s13592-0120175-4

Maia-Silva C., Hrncir M., Imperatriz-Fonseca V.L., Schorkopf D.L.P. (2016) Stingless bees (Melipona subnitida) adjust brood production rather than foraging activity in response to changes in pollen stores. $\mathrm{J}$ Comp Physiol A 202, 723-732. https://doi. org/10.1007/s00359-016-1095-y

Malagodi-Braga K.S., Kleinert A.M.P. (2004) Could Tetragonisca angustula Latreille (Apinae, Meliponini) be effective as strawberry pollinator in greenhouses? Aust J Agric Res 55, 771-773. https://doi.org/10.1071 /ar03240

Mello M. A. R., Rodrigues F. A., Costa L. F., Kissling W.D., Şekercioglu C.H., Marquitti, F.M., Kalko, E.K.V. (2015) Keystone species in seed dispersal networks are mainly determined by dietary specialization. Oikos 124, 1031-1039. https://doi.org/10.1111 /oik.01613

Michener C.D. (1974) The social behavior of the bees: a comparative study. Belknap Press of Harvard University Press, Massachusetts

Michener C.D. (2007) The Bees of the World. The John Hopkins University Press, Baltimore

Moure J.S., Urban D., Melo G.A.R. (Orgs.) (2012) Catalogue of Bees (Hymenoptera, Apoidea) in the Neotropical Region - online version. http://moure.cria.org. br/index. Accessed 27 August 2012

Nunes-Silva P., Hrncir M., Silva C.I., Roldão Y.S., Imperatriz-Fonseca V.L. (2013) Stingless bees, Melipona fasciculata, as efficient pollinators of eggplant (Solanum melongena) in greenhouses. Apidologie 44, 537-546. https://doi.org/10.1007 /s13592-013-0204-y

Oliveira R., Schlindwein C. (2009) Searching for a manageable pollinator for acerola orchards: the solitary oilcollecting bee Centris analis (Hymenoptera: Apidae: Centridini). J Econ Entomol 102, 265-273. https://doi. org/10.1603/029.102.0136

Ollerton J., Winfree R., Tarrant S. (2011) How many flowering plants are pollinated by animals? Oikos 120, 321-326. https://doi.org/10.1111/j.16000706.2010.18644.x

Pitts-Singer T.L., Cane J.H. (2011) The alfalfa leafcutting bee, Megachile rotundata: the world's most intensively managed solitary bee. Annu Rev Entomol 56, 221237. https://doi.org/10.1146/annurev-ento-120709144836

Potts S.G., Imperatriz-Fonseca V.L., Ngo H.T., Aizen M.A., Biesmeijer J.C., Breeze T.D., Dicks L.V., Garibaldi L.A., Hill R., Settele J., Vanbergen A.J. (2016) Safeguarding pollinators and their values to human well-being. Nature 540, 220-229. https://doi. org/10.1038/nature20588 
R Core Team (2015). R A Language and Environment for Statistical Computing. R Foundation for Statistical Computing, Vienna.

Renner S. (1983) The wide spread occurrence of anther destruction by Trigona bees in Melastomataceae. Biotropica 15, 251-256

Roubik D.W., Villanueva-Gutierrez R. (2009) Invasive Africanized honey bee impact on native solitary bees: a pollen resource and trap nest analysis. Biol J Linn Soc 98, 152-160. https://doi.org/10.1111/j.10958312.2009.01275.x

Sadeh A., Shmida A., Keasar T. (2007) The carpenter bee Xylocopa pubescens as an agricultural pollinator in greenhouses. Apidologie 38, 508-517. https://doi. org/10.1051/apido:2007036

Sedivy C., Dorn S. (2014) Towards a sustainable management of bees of the subgenus Osmia (Megachilidae; Osmia ) as fruit tree pollinators. Apidologie 45, 88105. https://doi.org/10.1007/s13592-013-0231-8

Shackleton K., Al Toufailia H., Balfour N.J., Nascimento F.S., Alves D.A., Ratnieks F.L.W. (2015) Appetite for self-destruction: suicidal biting as a nest defense strategy in Trigona stingless bees. Behav Ecol Sociobiol 69, 273-281. https://doi.org/10.1007/s00265-0141840-6

Slaa E.J., Sanchez-Chaves L.A., Malagodi-Braga K.S., Hofstede F.E. (2006) Stingless bees in applied pollination: practice and perspectives. Apidologie 37, 293-315. https://doi.org/10.1051/apido:2006022

Velthuis H.H.W., van Doorn A. (2006) A century of advances in bumblebee domestication and the economic and environmental aspects of its commercialization for pollination. Apidologie 37, 421-451. https://doi. org/10.1051/apido:2006019

Woodcock B.A., Edwards M., Redhead J., Meek W.R., Nuttall P., Falk S., Nowakowski M., Pywell R.F. (2013) Crop flower visitation by honeybees, bumblebees and solitary bees: Behavioural differences and diversity responses to landscape. Agric Ecosyst Environ $171,1-8$. https://doi.org/10.1016/j. agee.2013.03.005

Woodcock B.A., Garratt M.P.D., Powney G.D., Shaw R.F., Osborne J.L., Soroka J., Lindström S.A.M., Stanley D., Ouvrard P., Edwards M.E., Jauker F., McCracken M.E., Zou Y., Potts S.G., Rundlöf M., Noriega J.A., Greenop A., Smith H.G., Bommarco R., van der Werf W., Stout J.C., Steffan-Dewenter I., Morandin L., Bullock J.M., Pywell R.F.(2019) Meta-analysis reveals that pollinator functional diversity and abundance enhance crop pollination and yield. Nat Commun 10, 1481. https:/www.nature.com/articles/s41467-019-09393-6

Publisher's note Springer Nature remains neutral with regard to jurisdictional claims in published maps and institutional affiliations. 